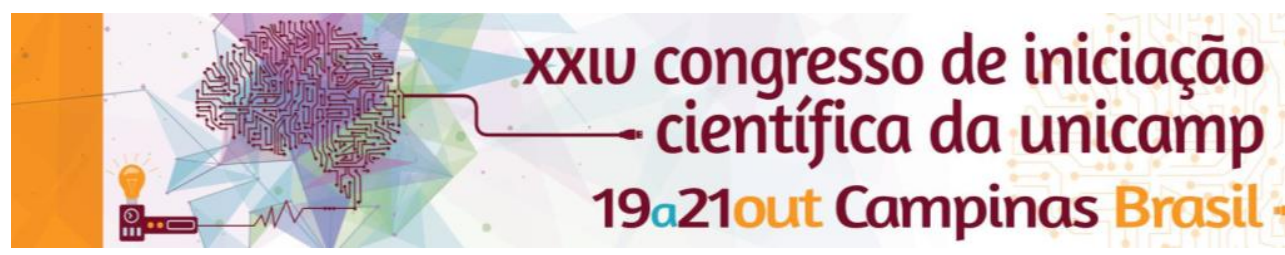

\title{
Desenvolvimento de máquina de prototipagem rápida
}

\author{
Alícia F. Machado, Larissa Meneghini Silva, Isadora Tomaz De Melo, Natalia Balero Mendonça (Monitora), \\ Eduardo Paiva Okabe (Orientador)
}

\begin{abstract}
Resumo
Neste projeto foram desenvolvidas atividades coletivas, onde todos os projetos inter-relacionados foram agrupados, e os alunos trabalharam para atingir o objetivo final: o desenvolvimento de duas impressoras tridimensionais, cujo objetivo é construir objetos de plástico; uma extrusora, que fabrica produtos contínuos, no caso deste projeto, o filamento.usado nas impressoras; e uma fresadora, ou seja, máquina utilizada para cortar, entalhar ou perfurar diversos tipos de materiais para que se consiga chegar na medida ou forma desejada. Foram montadas as estruturas básicas das máquinas para que no final seja possível construir protótipos a partir deste conjunto de máquinas.
\end{abstract}

\section{Palavras-chave}

Prototipagem rápida, modelagem tridimensional, programação de computadores.

\section{Introdução}

A prototipagem rápida, também conhecida como impressão 3D, é uma tecnologia de manufatura usada para construir automaticamente objetos físicos que usam fabricação de forma livre sólida. O processo começa com a obtenção de um projeto virtual criado por um aplicativo de modelagem, e então um programa de fatiamento gera - programa para a máquina de impressão 3D. Esta impressora lê os dados do programa (código G) e deposita camadas sucessivas de material fundido.

Um exemplo de software de modelagem que edita eletronicamente desenhos é o aplicativo Inkscape, que trabalha com documentos vetoriais, ou seja, ele gera um desenho através de um caminho de pontos de forma simples para o usuário, mas ao mesmo tempo próximo ao modelo usado pelo aplicativo de geração de programas para a impressora 3D.

Com intuito de desenvolver as habilidades necessárias e consolidar o conhecimento em prototipagem, foram montadas três máquinas importantes para a realização deste processo, e montagem dos equipamentos (extrusora, fresadora e impressoras 3D). Assim, os professores orientadores forneceram o conhecimento necessário aos alunos para o início da montagem das maquinas, o que compreende desde o estudo da eletrostática e eletrodinâmica até o trajeto da energia elétrica ao receptor eletrônico Arduíno, a fim de que os alunos somassem tais informações e as utilizassem para a conclusão do projeto.

\section{Resultados e Discussão}

Para comprovar e aprimorar a eficácia de cada mecanismo foram realizados testes e desenvolvidos cálculos para estabelecer as margens de erros e analisar os resultados.

Para calcular os desvios e avaliar a precisão da extrusão do filamento foi elaborada a seguinte tabela:
Tabela 1. Margens de erro do filamento da Extrusora..

\begin{tabular}{|l|c|c|c|}
\hline \multicolumn{1}{|c|}{ Analises } & Teste 1 & Teste 2 & Teste 3 \\
\hline Erro Absoluto & 1.887 & 0.15 & 0.013 \\
\hline Erro real & 0.078 & 0.0857 & 0.007 \\
\hline Diâmetro $(\mathrm{mm})$ & 0.149 & 0.02 & 0.1653 \\
\hline
\end{tabular}

Devido atrasos na entrega dos demais equipamentos (Fresadora e Impressoras 3D) e do longo tempo de montagem, não foi possível realizar os testes a tempo de inseri-los aos resultados alcançados.

\section{Conclusões}

Conclui-se que esse projeto cativa o aluno, pois desperta 0 interesse pela ciência, e em especial pela Engenharia de Manufatura, estimulando-nos a seguir essa profissão no futuro, a ter paciência para montar passo-a-passo o projeto, além de ensinar que o trabalho em equipe é fundamental para que se chegue ao resultado desejado.

\section{Agradecimentos}

Agradecemos aos professores orientadores e aos alunos monitores, da instituição FCA Unicamp, pelo apoio e auxilio fornecido.

Tutorial de Montagem Impressora 3D Graber i3 - GTMax3D. Disponível em: file://D:/Tutorial\%20Montagem\%20Graber\%20i3\%20GTMax3d\%20-

$\% 20$ Fase $\% 202$.pdf. Acessado em: 23 de junho de 2016

GORNI, Antonio Augusto. Introdução à prototipagem rápida e seus processos Disponível em: http://www.gorni.eng.br/protrap.html. Acessado em: 17 de março de 2016

Inkscape. Disponível em :〈http://pt.wikipedia.org/wiki/Inkscape〉 Acessado em 7 de janeiro de 2015

Objetivos do PIBIC. Disponível em:<http://cnpq.br/pibic> Acessado em 15 de janeiro de 2016 